\title{
A CONCEPT OF RESULTANT CORPORATE INNOVATIVENESS ASSESSMENT MODEL
}

\author{
Tomasz L. NAWROCKI \\ Silesian University of Technology, Faculty of Organization and Management, Zabrze; \\ tomasz.nawrocki@polsl.pl; ORCID: 0000-0002-2120-3494
}

\begin{abstract}
Purpose: The main reason for developing the model was to fulfil the gap in the scope of synthetic/aggregate measure of corporate innovativeness in terms of company's results in this area and their impact on its performance.
\end{abstract}

Design/methodology/approach: In the proposed concept two aspects have been considered: quantitative and qualitative results of company's innovation activity (i) and impact of this results on financial performance of company and its efficiency (ii). Due to the fact, that access to information on innovative activities results of companies is highly diversified, proposed model provides two versions to use: one, more general, based on public sources of data (Public Data Approach) and one, more detailed, based on data which should be collected through survey research (Survey Data Approach). The basis for corporate resultant innovativeness model creation was an assumption, that the ultimate market success of the company is not determined by how many innovative solutions it implements and introduces to the market and with what force it does it, but how these solutions will be accepted by the market and what economic benefits the company will receive due to them.

Findings: Proposed methodology of innovativeness assessment gives a chance to eliminate several key shortcomings of the so far used methods and concepts of corporate innovativeness measurement and assessment.

Research limitations/implications: Input data accessibility, development of knowledge (rules) bases needed to perform fuzzy inference.

Practical implications: Presented model gives an opportunity to assess and compare enterprises in terms of their resultant innovativeness and then to assess the impact of this innovativeness on their performance.

Social implications: Assessments generated by presented model can be basis for managerial decisions inside the assessed enterprise or investment decisions of investors in the capital market.

Originality/value: Original approach for aggregate corporate resultant innovativeness assessment that eliminates several weaknesses of methods used so far.

Keywords: corporate innovativeness evaluation, resultant innovativeness, financial performance, efficiency.

Category of the paper: Viewpoint, conceptual paper. 


\section{Introduction}

Since Schumpeter's vision of creative destruction (Schumpeter, 1960) innovation and innovativeness are among the major issues in the enterprise management (Prahalad, Hamel, 1990; Drucker, 1992; Porter, 1998). However, despite its high popularity in scientific research, the definitions of innovation and innovativeness are often understood in the literature in many different ways. Most often it is emphasized, that innovativeness is a specific ability or skill of an enterprise to search, implement, and disseminate innovations continuously (Pomykalski, 2001), as well as intention to be innovative, creative, open-minded or willing to change (Berthon et al., 1999; Kundu, and Katz, 2003). Thus, possessing it allows the enterprise to implement new products, processes, or ideas (Zaltman et al., 1973; Hult et al., 2004). More extended definitions present innovativeness as an organization's inclination to seek, create, and implement new products, technologies, services, markets, and management methods; to undertake actions in uncertain situations; and to monitor the market and competition, forecast market situations and react quickly to changes by breaking routines, changing ways of communicating, and developing new ways of organizing (Francik, 2003).

It should be also noted that many innovativeness definitions go beyond simple highlighting abilities or skills, emphasizing the results of its possession and use. In this way, innovativeness is the ability of an organization to control and maintain high dynamics of value creation, which manifests itself in using occasion to generate change and to process, as well as implement, new ideas in practice (Jin, Hewitt-Dundas, and Thompson, 2004) earlier than other enterprises do (Rogers, 1995). Innovativeness as an ability should also enable an effective allocation of resources, what should translate into creation of an optimal configuration of competitive advantage (Morgan, and Berthon, 2008).

Therefore, innovativeness can be seen in the context of widely understood organization's potential for creating innovation and continuous involvement in its development - the so-called potential innovativeness - and, on the other hand, in the context of specific effects of undertaken innovative activities and their impact on organization's financial results - the so-called resultant innovativeness (Yeung, Lai, and Yee, 2007; Nawrocki, 2012). Differentiating these two types of innovativeness is highly important, as wide innovative potential does not always translate into a considerable results of innovative activity and vice versa (Simpson, Siguaw, and Enz, 2006).

From the viewpoint of research on innovation phenomenon in enterprises and its management it is extremely important to determine how to assess corporate innovativeness. Developed over the last decades approaches to corporate innovativeness assessment (Oslo Manual - Guidelines for Collecting and Interpreting Innovation Data, Roger's methods, patent statistics, Frascati Manual - Guidelines for Collecting and Reporting Data on Research and Experimental Development, and many others) offer indeed a number of measures, but generally 
they do not allow to get a synthetic innovativeness assessment (Rogers, 1995; OECD, 2015; OECD and Eurostat, 2005; Nawrocki, 2015). In addition, these methodologies are based mostly on data, which are often difficult to reach (internal corporate data) or not necessarily reliable (surveys).

Therefore, continuing author's previous studies on corporate innovativeness assessment, as the main objective of this paper was adopted, which is a presentation of corporate resultant innovativeness assessment model concept based also on publicly available data. Proposed method will provide not only partial, but also a comprehensive understanding of enterprise's innovative activity results, and subsequently will enable conducting more in-depth research, in particular comparative analysis on innovativeness and its management.

\section{Basic assumptions and criteria of corporate resultant innovativeness assessment}

Proposed methodology of corporate resultant innovativeness assessment is supposed to be of universal character and may be used in particular for enterprises that publish annual reports (Nawrocki, 2012). It includes two aspects: quantitative and qualitative results of company's innovation activity (i) and impact of this results on company's financial performance (ii).

The legitimacy of separating the above-mentioned areas arises directly from the Oslo methodology, which is generally accepted basis for research on innovation activity of enterprises (OECD and Eurostat, 2005, OECD and Eurostat, 1997):

- number of introduced innovations in three years period (generally or in breakdown on product, process, organizational, marketing innovations),

- evaluation of introduced innovations from the viewpoint of their general and specific characteristics e.g.: level of novelty, complexity, diffusion capabilities, quality, usefulness, ... - LBIO Methodology (OECD and Eurostat, 1997),

- impact of company's innovation activity on its financial performance (e.g.: sales revenue growth rate, profit growth rate, total assets growth rate).

In addition to the abovementioned Oslo methodology, authors of numerous studies on corporate innovativeness or innovation activity also point to other possible criteria for measurement/evaluation of its results:

- patents or patent applications (Jung et al., 2008),

- patent citations (Makri, and Scandura, 2010),

- ratio of sales of new products to total sales (Czarnitzki, and Kraft, 2004),

- ratio of sales of new products to R\&D expenditures (Gumusluoglu, and Ilsev, 2009). 
As it can be seen, the current research in the area of measuring the results of innovative activity of enterprises provides a wide range of criteria for assessing this phenomenon. At this point, however, the attention should be paid to some problems of an application nature, which generally relate to the issue of obtaining adequately detailed, complete and comparable data.

As regards the first area (i), the difficulties often arise already on the level of information about the number and characteristics of innovative solutions brought into use by enterprises. The results of author's previous studies, performed for companies listed on the Warsaw Stock Exchange, show, that only about $20 \%$ of them inform about the number and characteristics of new solutions implemented/placed on market (mainly among enterprises from banking, chemical, information technology, machinery, pharmaceutical, media, energy and plastic sectors), but hardly any of them informs about their impact on the company's performance (Nawrocki, and Żabka, 2011). It is also worth to remember, that the results of innovative activities may relate to the issues of product, process, marketing or organization, and if companies inform about the results of innovative activities at all, usually they focus only on the first two types of innovations. Staying with the first area of corporate resultant innovativeness assessment it should also be noted that much greater difficulties concern information about the qualitative characteristics of innovative solutions. In the first place this is due to general gaps, or a vague description of them, and secondly highly subjective perception of some advantage over other solutions. Admittedly, some supplement to the annual reports and corporate websites for resultant innovativeness assessment are national or international patent statistics databases, but even this does not guarantee full information about the results of enterprises' innovative activity, because for various reasons (e.g. financial), not all new solutions are submitted to that type of databases.

As for the second area of corporate resultant innovativeness assessment (ii), the main problem lies in assigning the degree of impact on the financial results of company to the specific innovative solutions introduced by it. This is highly problematic, because different innovative solutions may affect company's performance with various intensity and in different time periods. Additionally, it should be noted that regardless of the impact of solutions introduced to the market, company's performance may be constantly burdened by the cost of research and development activity that remains in progress.

Taking into account the above considerations about corporate resultant innovativeness assessment, below two alternative model approaches have been shown (Table 1). First based on public data (PDA - Public Data Approach), and the second - based on data obtained through surveys (SDA - Survey Data Approach). 
Table 1.

Corporate resultant innovativeness assessment criteria in two model approaches

\begin{tabular}{|l|l|l|}
\hline & \multicolumn{1}{|c|}{ Public Data Approach } & \multicolumn{1}{c|}{ Survey Data Approach } \\
\hline
\end{tabular}

Source: own work.

Each of the presented approaches obviously has its advantages and disadvantages. In the case of the first one, the undoubted advantage is the ease of evaluating the resultant innovativeness and its repeatability, and the crucial disadvantage - approximate nature of received assessment, arising from gaps and shortcomings in public information disclosed by companies (mainly in the form of periodic reports or on corporate websites). On the other hand, in the case of the second approach, the evaluation is based admittedly on a much more detailed and complete data, that are consistent with the guidelines of the Oslo methodology, but also there is no guarantee of their credibility and receiving them (the two main threats associated with data collection through surveys), and carrying out regular evaluations is much more burdensome than in the first approach.

\section{General structure of corporate resultant innovativeness assessment model}

As it can be seen in Table 1 the fundamental difference between the indicated approaches of corporate resultant innovativeness assessment lies in the detail of input data for particular assessment criteria calculation. Therefore, the overall structure of corporate resultant innovativeness assessment model, regardless of the presented above approach, can be illustrated in a similar way (figure 1), but in the approach based on public data sources specific assessment criteria are of a general nature, while in the approach assuming the use of survey research for the purpose of gathering input data they relate to specific innovative solutions and their impact on performance of an enterprise. 


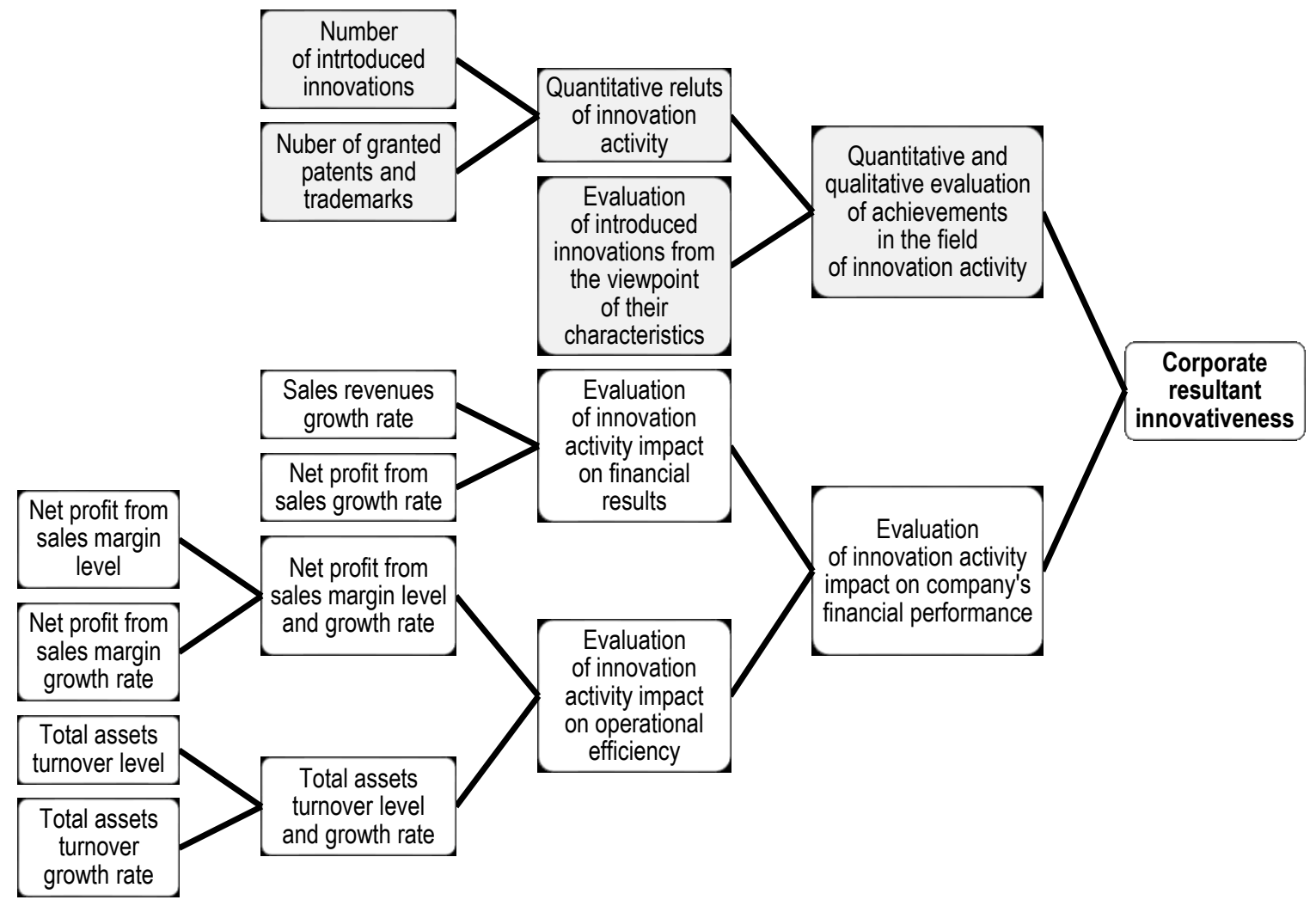

Figure 1. General structure of corporate resultant innovativeness assessment model. Source: own work.

In the proposed model, first it is assumed to obtain partial assessments within the basic criteria of corporate resultant innovativeness model. These assessments will result from the calculated ratios based on data from public sources or survey research (depending on the approach used). Then, on this basis, it is assumed to obtain increasingly aggregated assessments which are quantitative results of innovation activity, evaluation of introduced innovations from the viewpoint of their characteristics and evaluation of innovation activity impact on financial results and operational efficiency. These assessments are the basis for the calculation of the overall resultant innovativeness measurements, regarding quantitative and qualitative evaluation of achievements in the field of innovations and evaluation of innovation activity impact on company's financial performance, in order to obtain an overall corporate resultant innovativeness assessment in the final stage. In the context of aggregation of partial assessments, solutions from the field of multidimensional comparative analysis (e.g.: Strahl, 1978) or fuzzy logic (Piegat, 2003) can be used.

It should be also noted that the resultant innovativeness assessment of companies from the perspective of their overall perceived efficiency (PDA) may seem a bit controversial, because it leads to the conclusion, that in general one could put an equal sign between these two categories and treat them somewhat alternately. At the same time, one could try to undermine this approach to the problem, arguing that improving enterprise's efficiency is a result of another factor/factors rather than innovations implemented/introduced to the market. Being aware of the above-mentioned shortcomings of proposed solution, it was decided after all to go 
this path, assuming that nowadays enterprises, which do not develop through continuous implementation/introduction to the market of widely understood innovations, lose their competitiveness and ultimately, sooner or later, it reflects negatively on results of their business. In addition it was assumed, that the ultimate market success of a company is not determined by how many innovative solutions it implements and introduces to the market and with what force it does it, but how these solutions are adopted by the market and what economic benefits the company received through them. The validity of such reasoning is well reflected by the example of close competitors in the consumer electronics market - Apple Inc., Sony Corp. and Samsung Electronics (Figure 2).

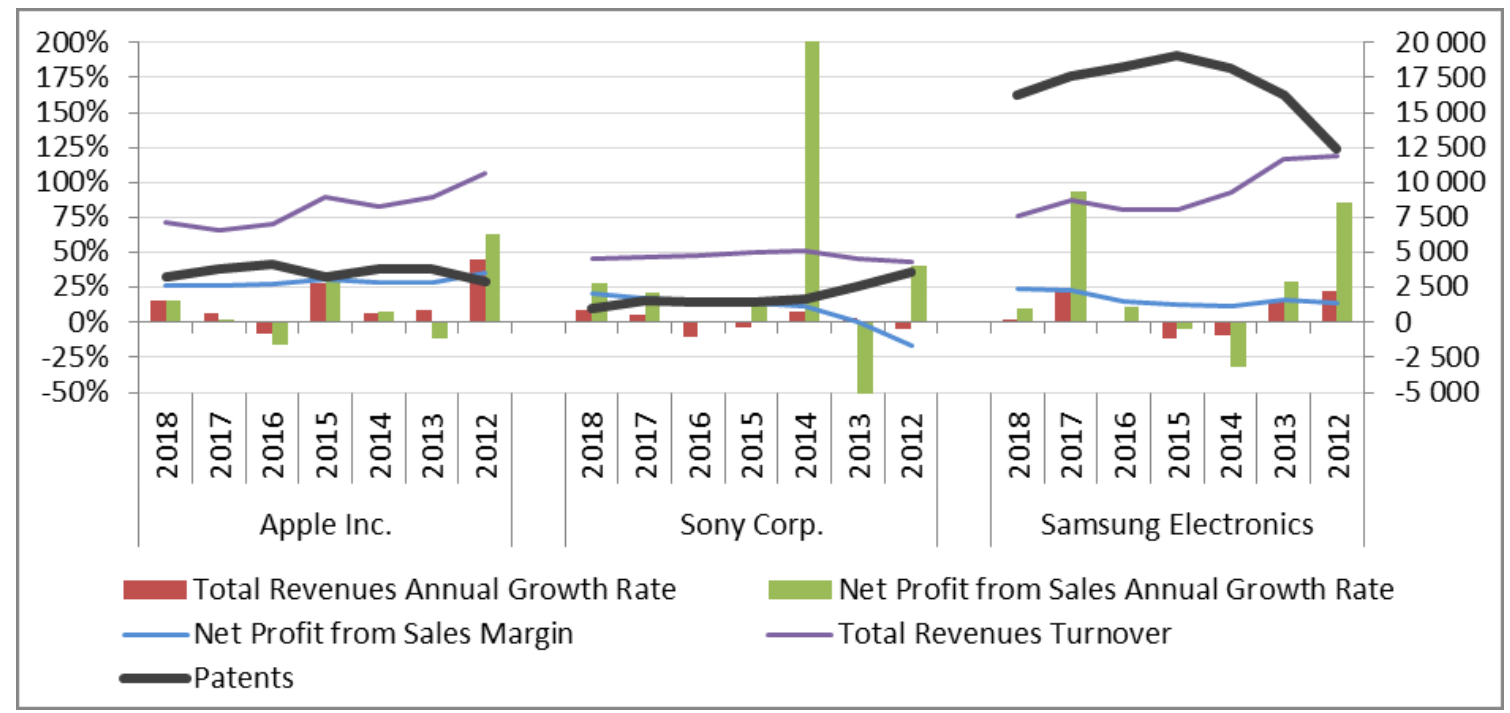

Figure 2. Patents statistics vs basic financial performance and operational efficiency criteria of Apple Inc., Sony Corp. and Samsung Electronics in 7 years period from 2012 to 2018. Source: Own work based on data from World Intellectual Property Organization (https://www.wipo.int/pct/en/) and annual financial reports of investigated companies.

As can be seen in Fig. 2, patent statistics of investigated companies do not translate into a significant positive change in their results or operational efficiency. In the latter case, one can even see quite clearly a negative dependence.

\section{Summary}

The methods and concepts of corporate innovativeness measurement and assessment used so far have some weaknesses that affect the credibility and reliability of the research results, in particular in the area of achievements in the field of innovation activity and its impact on company's financial performance. 
Proposed methodology of innovativeness assessment gives a chance to eliminate several key shortcomings of these methods through:

- focusing on one viewpoint of this category (resultant) but in a more accurate way,

- the possible use of criteria based on "hard" data derived from companies interim reports and corporate web pages (Public Data Approach), which most often will translate into more general but also more objective innovativeness assessments (alternatively, one always can try to collect the data using survey method - Survey Data Approach, but this way is exposed to subjectivity of received responses),

- the choice of assessment criteria regarding quantitative and qualitative aspects of innovation activity as well as its impact on financial performance of companies, and finally,

- the possibility of getting an aggregate evaluation of corporate resultant innovativeness taking into account its different dimensions (the effect of multidimensional comparative analysis or fuzzy logic use).

Being aware of some imperfections regarding the proposed solution (especially Public Data Approach), the basis for corporate resultant innovativeness model creation was an assumption, that the ultimate market success of a company is not determined by how many innovative solutions it implements and introduces to the market and with what force it does it, but how these solutions will be accepted by the market and what economic benefits the company will receive due to them.

At the same time, however, it must be emphasized that the presented concept of resultant innovativeness assessment model has theoretical nature and requires further considerations, verification of adopted criteria and detailed empirical research, especially including the development of knowledge (rules) bases needed to perform fuzzy inference.

\section{Acknowledgements}

This research was supported by 13/010/BK_19/0034. 


\section{References}

1. Berthon, P., Hulbert, J.M., and Pitt, L.F. (1999). To Serve or Create? Strategic Orientations toward Customers and Innovation. California Management Review, 42, pp. 37-58. doi: $10.2307 / 41166018$.

2. Czarnitzki, D., and Kraft, K. (2004). Firm leadership and innovative performance: Evidence from seven EU countries. Small Business Economics, 22, pp. 325-332. doi: 10.1023/ B:SBEJ.0000022209.72378.fe.

3. Drucker, P. (1992). Innowacja i przedsiębiorczość. Warszawa: PWE.

4. Francik, A. (2003). Sterowanie procesami innowacyjnymi w organizacji. Kraków: Wydawnictwo Akademii Ekonomicznej.

5. Gumusluoglu, L., and Ilsev, A. (2009). Transformational leadership and organizational innovation: The roles of internal and external support for innovation. Journal of Product Innovation Management, 26, pp. 264-277. doi: 10.1111/j.1540-5885.2009.00657.x.

6. Hult, G., Tomas, M., Hurley, R.F., and Knight, G.A. (2004). Innovativeness: its antecedents and impact on business performance. Industrial Marketing Management, 33, pp. 429-38. doi: https://doi.org/10.1016/j.indmarman.2003.08.015.

7. Jin, Z., Hewitt-Dundas, N., and Thompson, N.J. (2004). Innovativeness and performance: evidence from manufacturing sectors. Journal of Strategic Marketing, 12, pp. 255-66. doi: 10.1080/0965254042000308075.

8. Jung, D., Wu, A., and Chow, C.W. (2008). Towards understanding the direct and indirect effects of CEO's transformational leadership on firm innovation. The Leadership Quarterly, 19, pp. 582-594. doi: 10.1016/j.leaqua.2008.07.007.

9. Kundu, S.K., and Katz, J.A. (2003). Born-International SMEs: BI-Level Impacts of Resources and Intentions. Small Business Economics, 20, pp. 25-47.

10. Makri, M., and Scandura, T.A. (2010). Exploring the effects of creative CEO leadership on innovation in high-technology firms. The Leadership Quarterly, 21, pp. 75-88. doi: 10.1016/j.leaqua.2009.10.006.

11. Morgan, R., and Berthon, P. (2008). Market orientation, generative learning, innovation strategy and business performance inter-relationships in bioscience firms. Journal of Management Studies, 45(8), pp. 1329-53. doi: 10.1111/j.1467-6486.2008.00778.x.

12. Nawrocki, T. (2012). Innowacyjność produktowa przedsiębiorstw. Metodyka oceny na przykładzie spółek giełdowych. Warszawa: CeDeWu.

13. Nawrocki, T. (2015). Problematyka pomiaru i oceny innowacyjności przedsiębiorstw, Zeszyty Naukowe Politechniki Śląskiej, Seria: Organizacja i Zarządzanie, 79, pp. 217-26.

14. Nawrocki, T., and Żabka, A. (2011). Działalność innowacyjna spółek giełdowych, Ekonomika i Organizacja Przedsiębiorstwa, 11, pp. 3-12. 
15. OECD and Eurostat (1997). Oslo Manual. Guidelines for Collecting and Interpreting Innovation Data. Paris: OECD Publishing. https://doi.org/10.1787/9789264192263-en.

16. OECD and Eurostat (2005). Oslo Manual. Guidelines for Collecting and Interpreting Innovation Data. Paris: OECD Publishing. https://doi.org/10.1787/9789264013100-en.

17. OECD (2015). Frascati Manual. Guidelines for Collecting and Reporting Data on Research and Experimental Development - The Measurement of Scientific, Technological and Innovation Activities. Paris: OECD Publishing. https://doi.org/10.1787/ 9789264239012-en.

18. Piegat, A. (2001). Fuzzy Modeling and Control. Berlin Heidelberg: Springer-Verlag.

19. Pomykalski, A. (2001). Innowacje. Łódź: Wydawnictwo Politechniki Łódzkiej.

20. Porter, M.E. (1998). Competitive Advantage: Creating and Sustaining Superior Performance. New York: Free Press.

21. Prahalad, C.K., Hamel, G., (1990) The Core Competence of the Corporation. Harvard Business Review, 68, pp. 79-90. doi: 10.1007/3-540-30763-X_14.

22. Rogers, E.M. (1995). Diffusion of innovations. New York: The Free Press.

23. Schumpeter, J.A. (1960). Teoria rozwoju gospodarczego. Warszawa: PWN.

24. Simpson, P.M., Siguaw, J.A., and Enz, C.A. (2006). Innovation orientation outcomes: the good and the bad. Journal of Business Research, 59, pp. 1133-41. doi:10.1016/ j.jbusres.2006.08.001.

25. Strahl, D. (1978). Propozycja konstrukcji miary syntetycznej, Przegląd Statystyczny, 25, 2, pp. 205-215.

26. Yeung, A.C.L., Lai, K., and Yee, R.W.Y. (2007). Organizational learning, innovativeness and organizational performance: a qualitative investigation, International Journal of Production Research, 45, pp. 2459-77. doi: 10.1080/00207540601020460.

27. Zaltman, G., Duncan, R., and Holbeck, J. (1973). Innovativeness and Organizations. New York: Wiley. 